\title{
A Novel X-linked Combined Immunodeficiency Disease
}

\author{
Edward G. Brooks," Frank C. Schmalstieg," Daniel P. Wirt," Howard M. Rosenblatt, ${ }^{\star}$ Linda T. Adkins, \\ Donald P. Lookingbill," Helen E. Rudloff," Tamara A. Rakusan," and Armond S. Goldman* \\ *Departments of Pediatrics, Pathology, Human Biological Chemistry and Genetics, and Microbiology, University of Texas \\ Medical Branch, Galveston, Texas 77550; ${ }^{\circ}$ Department of Pediatrics, Baylor College of Medicine, Houston, Texas; 77030 \\ ${ }^{\S}$ Department of Medicine, Pennsylvania State University College of Medicine, Hershey, Pennsylvania; 17033 \\ and "Children's Hospital, George Washington University, Washington, DC 20010
}

\begin{abstract}
A novel $\mathrm{X}$-linked combined immunodeficiency disease was found in five living males in an extended family in the United States. The age of the affected males ranged from 2.5 to $34 \mathrm{yr}$. The most prominent clinical abnormalities were a paucity of lymphoid tissue; recurrent sinusitis, otitis media, bronchitis, and pneumonia; severe varicella; and chronic papillomavirus infections. The principal immunologic features of the disorder were normal concentrations of serum immunoglobulins but restricted formation of IgG antibodies to immunogens; normal numbers of $B$ cells and NK cells but decreased numbers of $\mathrm{CD4}^{+}$and $\mathrm{CD8}^{+} \mathrm{T}$ lymphocytes, particularly the CD45RA ${ }^{+}$ subpopulations; diminished proliferative responses of blood $T$ cells to allogeneic cells, mitogens and antigens; and decreased production of IL-2 by mitogen stimulated blood lymphocytes. Thus, affected males in this family carry an abnormal gene on their $\mathrm{X}$ chromosome that results in a combined immunodeficiency that is distinct from previously reported disorders. ( $J$. Clin. Invest. 1990. 86:1623-1631.) Key words: helper T cells • suppressor $T$ cells $\bullet$ virgin $T$ cells $($ CD45RA) • memory $T$ cells (CD45RO) • IgG antibodies
\end{abstract}

\section{Introduction}

During the past four decades several types of X-linked immunodeficiency diseases have been described including Bruton's disease (1-5), the hyper-IgM antibody deficiency $(2,3,5)$, the Wiskott-Aldrich syndrome (WAS) $(2,3,6-9)$, a lymphoproliferative disorder (10-12), and the most common types of chronic granulomatous disease (CGD) $(2,13,14)$ and of severe combined immunodeficiency (SCID) ${ }^{1}(2,3,15-18)$. Those discoveries illuminated many functions of the immune system

The material in this paper was presented in part to the Southern Society for Pediatric Research on 18 January 1990 and the Society for Pediatric Research and the American Pediatric Society on 9 May 1990.

Address reprint requests to Armond S. Goldman, M. D., Division of Immunology and Allergy, Department of Pediatrics, Room C2-35 Child Health Center, University of Texas Medical Branch, Galveston, TX 77550.

Received for publication 7 February 1990 and in revised form 7 May 1990.

1. Abbreviations used in this paper: $\mathrm{CD}$, cluster of differentiation; $\mathrm{PE}$, phycoerythrin; PHA-P, phytohemagglutinin P; SCID, severe combined immunodeficiency; TNF, tumor necrosis factor.

J. Clin. Invest.

(c) The American Society for Clinical Investigation, Inc. $0021-9738 / 90 / 11 / 1623 / 09 \quad \$ 2.00$

Volume 86, November 1990, 1623-1631 and led to investigations of the role of the $\mathrm{X}$ chromosome in the genesis of that system. Genes for each of those X-linked immunologic deficiencies were mapped to specific regions of the $\mathrm{X}$ chromosome (19-28). Furthermore, in X-linked CGD the resultant protein abnormality, a deficiency in the production of the $90-\mathrm{kD}$ carrier protein for cytochrome b245, was elucidated $(29,30)$, and a sialic acid rich glycoprotein (GP-115) was found to be deficient in certain cases of WAS (31). The most proximal protein abnormalities in other $\mathrm{X}$ linked immune deficiencies have not, however, been demonstrated.

Because of the importance of the $X$ chromosome in the development of the immune system, we report a new type of $\mathrm{X}$-linked immunodeficiency characterized by certain abnormalities in the number and functions of $T$ lymphocytes and in the formation of specific IgG antibodies.

\section{Methods}

Subject selection: human research assurances. The research was approved by the institutional review boards of the medical schools, and informed consent was obtained from participating subjects. Once the index case was identified (Fig. 1, subject VI-P), we discovered that he was a member of an extended family of British origin that contained four other living males who displayed chronic or recurrent infections (Fig. 1; subjects V-E, VI-A, VI-K, and VII-A). The medical status of all members of the family was documented. In particular, the histories of deceased sons of suspected female carriers were reviewed to determine whether their clinical presentations were similar to those of the living symptomatic males. In addition, immunologic studies were conducted on the suspected affected males and some asymptomatic members of the family.

Immunoglobulin-antibody studies. Serum concentrations of immunoglobulins and of IgG subclasses were quantified by nephelometry (32) and an ELISA (33), respectively. Titers of serum IgG, IgA, and IgM antibodies to tetanus and diphtheria toxoids (Lederle Laboratories, Pearl River, NY) and to pneumococcal polysaccharides (Lederle Laboratories) were measured in the patients and 10 normal children by an ELISA (34) before and 10-21 d after immunization with the aforementioned immunizing agents. The isotypes of serum antibodies to Candida albicans (Hollister-Stier, Spokane, WA) and to a pool of Escherichia coli polysaccharide antigens were determined by the same method. 96-well polystyrene plates (Dynatech Laboratories, Chantilly, VA) were coated with $5 \mu \mathrm{g} / \mathrm{ml}$ of antigen. After washing and blocking with BSA, serum was diluted $(1: 2$ to $1: 10,000)$ and incubated for $2-3 \mathrm{~h}$ at $37^{\circ} \mathrm{C}$. After washing, bound antibodies were detected with specific rabbit or goat antibodies to human IgG, IgA, or IgM conjugated to horseradish peroxidase (Dako Corp., Carpinteria, CA). The color reaction was developed with diaminobenzidine and measured spectrophotometrically with an automated system (Bio-Rad Laboratories, Richmond, CA). The resultant titers were expressed as a percent of antibody activity of a pool of sera from normal adults.

Flow cytometry. The surface phenotypes of blood mononuclear leukocytes obtained by Ficoll-Hypaque density gradient centrifugation 


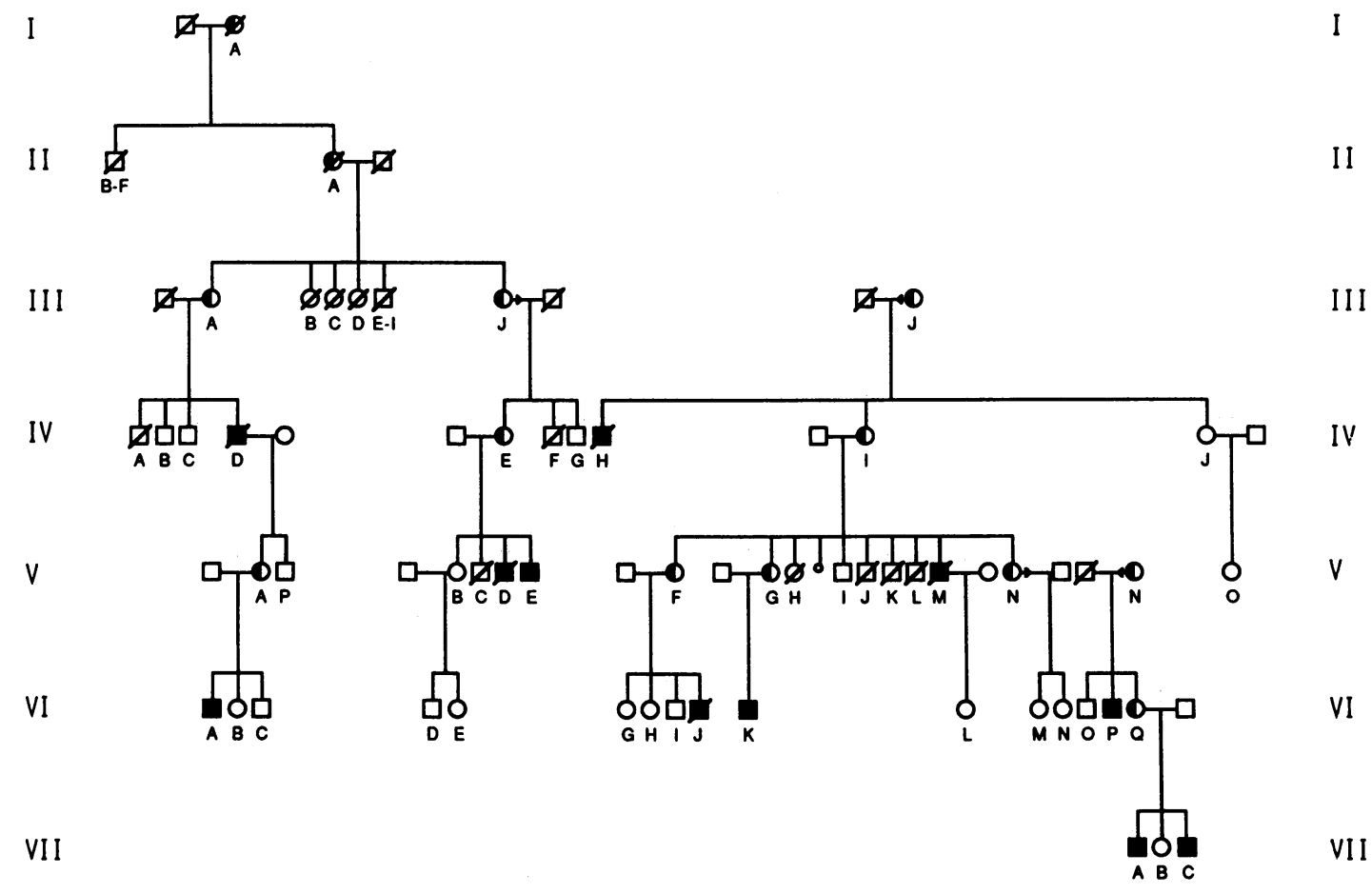

Figure 1. The pedigree chart of the family. Living affected males ( $\square$ ), deceased males with a high probability of the disease ( $\square$ ), obligate carriers (o), other deceased family members $(\square, \varnothing)$, and a child who lived $<1 \mathrm{~d}(\circ)$ are depicted. The generations are designated by Roman numerals and members of a generation by capital letters.

were examined by multicolor flow cytometry $(35,36)$ with a flow cytometer equipped with a $15-\mathrm{mW}$ argon-ion laser tuned to $488 \mathrm{~nm}$ (Becton-Dickinson FACScan, Mountain View, CA) and murine monoclonal antibodies (Becton-Dickinson, unless otherwise specified) to human leukocyte cluster of differentiation $(C D)$ antigens. Those antibodies were conjugated to FITC, phycoerythrin (PE), or biotin. Unconjugated antibodies were detected with goat FITC conjugated polyclonal antibodies $\left(\mathrm{F}\left[\mathrm{ab}^{\prime}\right]_{2}\right.$ fragments) to murine IgG (Jackson ImmunoResearch Laboratories, West Grove, PA) or rat monoclonal antibodies to murine IgM kappa light chains (Becton-Dickinson). Biotinylated antibodies were followed by a PE-Texas red conjugate bound to avidin (Duochrome, Becton-Dickinson).

The specificities of the monoclonal antibodies were as follows: CD1a (Leu-6), CD3 (Leu-4), CD4 (Leu-3a \& b), CD8 (Leu-2a), CD16 (Leu-11c), CD19 (Leu-12), CD20 (Leu-16), CD45RA (Leu-18), CD45RO (UCHL1, Dako Corp.), Leu-8, IgM, HLA-DR, T cell receptors of the $\alpha / \beta$ (WT31) and $\gamma / \delta$ types (TCR $\delta 1$; T Cell Sciences, Inc., Cambridge, MA), and $\alpha$-chains of the IL-2 receptor (IL-2R, CD25).

In analysis of single-color and two-color flow cytometric data, an electronic gate was set on the lymphocyte population based on forward-angle vs. right-angle light scatter. Then, quadrant markers were set using matched isotype controls. When three-color flow cytometry was performed, additional monoclonal antibodies conjugated to biotin were used. The three-color data were analyzed by using LYSYS software (Becton-Dickinson). (a) Lymphocytes were gated as previously described. (b) A contour graph of FITC-conjugated CD45RA (Leu-18) vs. PE-labeled CD45RO (UCHL1, indirectly detected with PE-conjugated rat antibodies to murine IgM kappa light chains) was generated for the total lymphocyte population. Quadrant markers were set so that the percentage of positive cells for each antibody was equivalent to the percentage of positive cells obtained by single-color analysis using each antibody. (c) A gate was set on Duochrome labeled cells, CD4 (Leu-3a), based on the percentage of positive cells obtained by singlecolor analysis with this antibody. Using the same quadrant markers determined in step 2, a histogram of FITC conjugated CD45RA (Leu-18) vs. PE-labeled CD45RO (UCHL1) was generated for the cells in the Duochrome positive gate.

Becton-Dickinson CaliBrite beads were run before analysis to monitor instrument performance and to set detector levels for the forward and right-angle light scatter and the fluorescence 1 (FL1) and fluorescence 2 (FL2) channels. For two and three-color analyses, compensation settings (FL1 - \%FL2 $=0.7 \pm 0.1$; FL2 $-\% F L 1=26.4 \pm 1.9$; FL2 $-\%$ FL3 $=26.0 \pm 4.3 ;$ FL3 $-\%$ FL2 $=51.1 \pm 9.8$ ) and the fluorescence 3 (FL3) detector $(620 \pm 17 \mathrm{~V})$ were optimized for each subject. The compensation settings represented the percentage of the FL $(x)$ signal amplitude subtracted from the FL (y) signal amplitude to compensate for the spectral overlap of fluorescent dyes $(F L 1=$ fluorescein, FL2 = phycoerythrin, FL3 = phycoerythrin-Texas red conjugate).

Lymphocyte stimulation. The incorporation of $\left[{ }^{3} \mathrm{H}\right]$-thymidine into blood lymphocytes after stimulation with phytomitogens, $C$. albicans, or allogeneic cells was measured. Blood mononuclear leukocytes $\left(2 \times 10^{5} / 200 \mu \mathrm{l}\right)$ were incubated in $5 \% \mathrm{CO}_{2}$ for $72 \mathrm{~h}$ with graded concentrations of phytohemagglutinin P (PHA-P, 4-32 $\mu \mathrm{g} / \mathrm{ml}$; Difco, St. Louis, MO), Con A (1.25-12.5 $\mu \mathrm{g} / \mathrm{ml}$; Sigma Chemical Co.); pokeweed mitogen (PWM, 1:400-1:10; Grand Island Biologicals, Grand Island, NY) or recombinant human IL-2 (10-400 U; Amgen Carp., Thousand Oaks, CA). The response to $C$. albicans (Hollister-Stier) was measured in a similar fashion except the cultures were harvested at $5 \mathrm{~d}$. In the mixed lymphocyte reaction, responder cells $\left(2 \times 10^{5}\right.$ blood mononuclear cells) from the patients were cultured for $5 \mathrm{~d}$ with $2 \times 10^{5}$ normal irradiated (3,000 rad) allogeneic stimulator cells. $1 \mu \mathrm{Ci}$ normal irradiated $(3,000 \mathrm{rad})$ allogeneic stimulator cells. $1 \mu \mathrm{Ci}$ of $\left[{ }^{3} \mathrm{H}\right]$-thymidine was added to each culture $4 \mathrm{~h}$ before harvesting, and the incorporation of the isotope into nuclei of the cells was measured in cpm by scintillation spectroscopy.

Cytoxicity assay. The cytotoxicity of blood mononuclear cells (NK cell activity) to $\mathrm{K} 562$ tumor cells labeled with ${ }^{51} \mathrm{Cr}$ was measured in a 4 $\mathrm{h}$ assay as previously described (37). 
Interleukin-lymphokine production. The production of IL-2 was measured by assaying the proliferative effects of culture supernatant fluids on a murine T-cell line (38). Blood mononuclear cells were stimulated with PHA-P for $24 \mathrm{~h}$. Serial dilutions of supernatant fluids from the cultures were incubated at $37^{\circ} \mathrm{C}$ for $24 \mathrm{~h}$ in microtiter plates (Costar, Inc., Cambridge, MA) with longstanding cultures of IL-2-dependent murine cytotoxic T cells (CTLL-2; American Type Culture Collection, Bethesda, MD). The incorporation of $\left[{ }^{3} \mathrm{H}\right]$-thymidine in these cells was measured as previously indicated.

Interferon activity of supernatant fluids obtained from PHA-Pstimulated blood lymphocytes was measured by using a viral plaque inhibition assay with human WISH cells (39). A standard amount of recombinant interferon $\alpha$ A/D (Hoffman LaRoche, Nutley, NJ) was used as a positive control. Tumor necrosis factor (TNF) activity was assessed by the cytotoxic effects of culture supernatant fluids from PHA-P- or Con A-stimulated blood lymphocytes upon a TNF-sensitive murine fibroblast cell line treated with actinomycin D (40). Recombinant human TNF- $\alpha$ (Genzyme Corp., Boston, MA) was used as a positive control.

Statistical analyses. Group data are presented as the mean \pm SD. Differences between lymphocyte subpopulations or lymphocyte responses from affected males and normal control subjects were tested by an unpaired Student's $t$ test.

\section{Results}

Genetic and clinical features. A study of the family history indicated that the affected males had an X-linked disorder most likely affecting specific immune responses (Fig. 1). A synopsis of the clinical features of the five living affected males with this X-linked disorder are presented in Table I. The historical findings on many deceased males in the family were similar to those patients (Fig. 1) including chronic sinopulmonary infections in subject IV-D, severe vaccinia and fatal varicella in subject V-D, a lethal acute pneumonia in subject V-M, and a fatal staphylococcal sepsis in subject VI-J. In addition, a large number of males died in infancy or early childhood of suspected infections. The clinical features of three of the living affected males are described in detail.

Patient 1 (Fig. 1, subject No. VI-P). The index case, a 17-yr-old Caucasian male, experienced repeated infections of the middle ear, paranasal sinuses, and lower respiratory tract

Table I. Clinical Features of Living Affected Males

\begin{tabular}{lccccc}
\hline & \multicolumn{5}{c}{ Subjects } \\
\cline { 2 - 6 } & V-E & VI-A & VI-K & VI-P & VII-A \\
\hline Age $(y r)$ & 34 & 12 & 9.0 & 16.5 & 2.5 \\
Otitis media & $++*$ & ++ & ++ & ++++ & + \\
Sinusitis & + & + & + & ++++ & ++ \\
Bronchitis & + & + & + & +++ & + \\
Pneumonia & + & + & - & ++ & + \\
Varicella & +++ & - & +++ & +++ & - \\
Herpes & - & - & + & ++ & + \\
Papillomavirus & ++++ & ++ & + & +++ & -
\end{tabular}

* Documented infections and some estimation of their frequency or severity are designated by plus $(+)$ signs. No known infections are designated by a minus $(-)$ sign. since infancy despite treatments with antibiotics. His clinical course was also marked by a near-fatal varicella infection at age $3 \mathrm{yr}$ and the appearance of many warts on the forearms and hands at age $10 \mathrm{yr}$.

When he was seen in the University of Texas Medical Branch at age $16 \mathrm{yr}$, he displayed $(a)$ herpes simplex virus type 1 lesions of the forehead, the right external ear, the right eyelid, and the infranasal area that were secondarily infected with Staphylococcus aureus; (b) chronic bilateral otitis media and sclerosis of the mastoid processes; $(c)$ severe pansinusitis; $(d)$ widespread reticular-nodular and suspected bronchiectatic changes in both lungs; $(e)$ many verrucae on the hands and wrists; $(f)$ undetected tonsils, adenoids, or subcutaneous lymph nodes; and $(g)$ growth retardation (body weight at the fifth percentile for age $15 \mathrm{yr}$; body height at the fifth percentile for age $14.5 \mathrm{yr}$ ). The herpes subsided without treatment; the $S$. aureus infection responded to treatment with intravenous nafcillin and topical antibiotics.

A defect in host defenses was suspected. The sweat chloride concentration, serum C3 level (114 mg/dl), blood neutrophil counts $\left(>2,000 / \mathrm{mm}^{3}\right)$, the chemotactic response of neutrophils to zymosan-activated serum or to $N$-formylmethionyl peptides in subagarose plates (leading front, 4.7 and 2.8 times greater than that of unstimulated cells, respectively), chemiluminescence response of stimulated neutrophils to $4 \beta$-phorbol $12 \beta$-myristate $13 \alpha$-acetate (Sigma Chemical Co.) (seven times greater than unstimulated cells), and adenosine deaminase and purine nucleoside phosphorylase activities in RBCs (data not shown) were normal. In contrast, deficiencies in blood $\mathrm{T}$ lymphocytes and specific IgG antibodies were found (Tables II-IV; Figs. 2-4).

Patient 2 (Fig. 1, subject No. VII-A). This 2.5-yr-old Caucasian male, a nephew of the first patient, seemed well until age 1 yr when he developed recurrent otitis media, sinusitis, and bronchitis. Physical examination and upper airway radiograms revealed a paucity of lymphoid tissue. Although no herpetic lesions were evident, nasal and pharyngeal cultures for herpes virus type 1 were repeatedly positive. Immunologic investigations revealed a pattern of abnormalities that were similar to the first patient (Tables II-IV; Figs. 2 and 4). The respiratory infections responded quickly to treatment with oral ampicillin. Since then he had one episode of oral herpes, one bout of pneumonia, and recurrent sinusitis.

Patient 3 (Fig. 1, subject No. VI-K). This 9-yr-old Caucasian male, a maternal cousin of the first patient, developed recurrent upper respiratory infections including otitis media at age $3 \mathrm{mo}$. Aside from facial eczema, he was well until age 20 mo when he was hospitalized at Baylor College of Medicine for severe varicella characterized by large bullous lesions and oral involvement. Secondary infections of the cutaneous lesions with $S$. aureus responded favorably to systemic antibiotic therapy. At age $7 \mathrm{yr}$, lip lesions that were suggestive of herpes and which were positive by Tzanck smear were treated for 3 wk with acyclovir. Immunologic studies conducted at Baylor revealed normal serum concentrations of immunoglobulins except for an elevated IgE (840 IU/ml), normal titers of isohemagglutinins, normal serum levels of $\mathrm{C} 3$ and $\mathrm{C} 4$, and a normal reduction of nitroblue tetrazolium by stimulated blood neutrophils. Deficits in the number and proliferative abilities of $T$ cells were, however, found. Although the total serum antibody 
Table II. Phenotypes of Blood Lymphocytes from the Patients Detected by Two-Color Flow Cytometry

\begin{tabular}{|c|c|c|c|c|c|c|c|}
\hline Cells $/ \mathrm{mm}^{3}$ & V-E & VI-A & VI-K & VI-P & VII-A & Patients & Normal \\
\hline Lymphocytes & 656 & 1180 & 1060 & 1342 & 735 & $994 \pm 292$ & $2101 \pm 190$ \\
\hline \multicolumn{8}{|l|}{ B cells } \\
\hline $\mathrm{CD} 9^{+}$ & 77 & 564 & 201 & 517 & 207 & $313 \pm 214$ & $210 \pm 128$ \\
\hline $\mathrm{CD}^{+} 0^{+}$ & 67 & 527 & 191 & 204 & 196 & $237 \pm 171$ & $193 \pm 105$ \\
\hline \multicolumn{8}{|l|}{$\mathrm{T}$ cells } \\
\hline $\mathrm{CD}^{+}$ & 304 & 195 & 753 & 722 & 415 & $478 \pm 250$ & $1534 \pm 220$ \\
\hline $\mathrm{CD}^{+}$ & 83 & 73 & 265 & 220 & 140 & $156 \pm 84$ & $784 \pm 167$ \\
\hline CD45RA $^{+}$ & 37 & 34 & 32 & 42 & 40 & $37 \pm 4$ & $517 \pm 235$ \\
\hline $\mathrm{CD} 45 \mathrm{RA}^{-}$ & 51 & 52 & 265 & 232 & 115 & $143 \pm 100$ & $469 \pm 141$ \\
\hline $\mathrm{CD}^{4} 5 \mathrm{RO}^{+}$ & 77 & 42 & 148 & 184 & 122 & $115 \pm 56$ & $580 \pm 123$ \\
\hline $\mathrm{CD} 45 \mathrm{RO}^{-}$ & 9 & 26 & 21 & 13 & 15 & $17 \pm 7$ & $215 \pm 83$ \\
\hline Leu $8^{+}$ & - & - & - & 164 & 123 & - & $755 \pm 177$ \\
\hline Leu $8^{-}$ & - & - & - & 52 & 14 & - & $76 \pm 43$ \\
\hline $\mathrm{CD}^{+}$ & 195 & 225 & 466 & 466 & 180 & $306 \pm 147$ & $674 \pm 96$ \\
\hline $\mathrm{CD}^{4} 5 \mathrm{RA}^{+}$ & 120 & 175 & 350 & 236 & 112 & $199 \pm 98$ & $631 \pm 119$ \\
\hline $\mathrm{CD} 45 \mathrm{RA}^{-}$ & 44 & 57 & 95 & 236 & 82 & $103 \pm 77$ & $143 \pm 52$ \\
\hline $\mathrm{IL}^{-}-\mathrm{R}^{+}$ & 19 & 20 & 24 & 31 & 51 & $29 \pm 13$ & $185 \pm 111^{*}$ \\
\hline \multicolumn{8}{|l|}{ NK cells } \\
\hline $\mathrm{CD}^{+} 6^{+}$ & 283 & 342 & 85 & 358 & 74 & $228 \pm 138$ & $338 \pm 136$ \\
\hline \multicolumn{8}{|l|}{ HLA-DR ${ }^{+}$} \\
\hline Total & 271 & 756 & 498 & 750 & 570 & $569 \pm 200$ & $729 \pm 247$ \\
\hline T-cells & 138 & 132 & 265 & 475 & 323 & $267 \pm 143$ & $458 \pm 222$ \\
\hline
\end{tabular}

Group data are presented (mean \pm SD). Missing data are designated by a minus sign $(-)$. ${ }^{*}$ These values for IL-2- $R^{+} \mathrm{T}$ cells were somewhat higher than a larger group of normal subjects tested in our laboratory because of high values in two of our concurrent control subjects.

titers to tetanus and diphtheria toxoids rose significantly, IgG antibody responses to those immunogens were poor (data not shown).

Subsequently, he experienced recurrent oral herpes infections, warts on the hands, and sinobronchial infections. Physical examination at age 9 yr revealed papillomavirus infections of the hands, purulent nasal secretions and sputum, otitis media, and scanty lymphoid tissue. The results of immunologic investigations conducted at age $9 \mathrm{yr}$ (Tables II-IV) were similar to previous data from this patient and to those found in subjects VI-P and VII-A.

Immunoglobulin-antibody studies. The serum concentrations (milligrams per deciliter) of the immunoglobulins of these patients were normal (IgG, 804-1,340; IgA, 122-184;

Table III. Expression of CD45RA and CD45RO on Peripheral Blood CD $4^{+}$Cells from Four Patients and 10 Normal Adults Detected by Three-Color Flow Cytometry

\begin{tabular}{lcc}
\hline \multicolumn{1}{c}{ Subpopulations } & Patients & Normals \\
\hline $\mathrm{CD}^{2} 5 \mathrm{RA}^{-} \mathrm{CD} 45 \mathrm{RO}^{-}$ & 0 & 0 \\
$\mathrm{CD}^{-}$ & $16 \pm 8$ & $144 \pm 63$ \\
$\mathrm{CD}^{+} \mathrm{CD} 5 \mathrm{RA}^{+} \mathrm{CD} 45 \mathrm{RO}^{-}$ & $25 \pm 8$ & $313 \pm 217$ \\
$\mathrm{CD}^{+}$ & $134 \pm 83$ & $312 \pm 207$ \\
& & \\
\hline
\end{tabular}

The total numbers of cells in each subpopulation for each patient were calculated by multiplying the total number of $\mathrm{CD} 4^{+}$cells by the percent of cells for each category. Group data are presented as the mean $\pm \mathrm{SD}$ of the absolute number of cells per cubic millimeter.
IgM, 99-183) although some decrease in the concentrations of IgG2 was found in two cases (VI-P, $31 \mathrm{mg} / \mathrm{dl}$; VII-A, 27 $\mathrm{mg} / \mathrm{dl}$ ). The isotypes of serum antibodies to ubiquitous microbial antigens and to immunizing agents (tetanus and diphtheria toxoid; pneumococcal polysaccharides) were investigated in detail in subjects VI-P and VII-A. The IgM and IgA antibody titers were similar to those found in a group of control children or in a large pool of sera obtained from normal adults, although specific serum IgM antibodies fell or failed to rise substantially after immunizations. Significant titers of serum IgG antibody were detected, however, to $C$. albicans in subject VI-P (1:42 versus 1:20 in the pool of normal adult sera). The titers of serum IgG antibodies to the other antigens including those used in the immunization studies were very low or undetectable (see Fig. 2 for the antibody studies to diphtheria toxoid) despite repeated immunizations. Poor serum IgG antibody responses were found in the three other patients who were tested before and 2 wk after one immunization with one or more of the previously described antigens (data not shown).

Flow cytometry of blood lymphocytes. The numbers of B cells $\left(\mathrm{CD} 9^{+}\right.$and $\left.\mathrm{CD} 20^{+}\right)$and $\mathrm{NK}$ cells $\left(\mathrm{CD}^{+} 6^{+}\right)$in the patients were similar to seven normal controls (Table II). The relative frequencies of blood lymphocytes from these patients that displayed class I (data not shown) or class II (Table II) major histocompatibility antigens were normal or increased. There was no evidence of immature $\left(\mathrm{CDla}^{+}\right) \mathrm{T}$ cells in the peripheral blood. The absolute numbers of $\mathrm{CD}^{+} \mathrm{T}$ cells were significantly reduced $(P<0.01$; Table II). Furthermore, the deficiencies were remarkable in $\mathrm{CD}^{+}$and $\mathrm{CD} 8^{+}$cells $(P$ $<0.001$ and 0.01 , respectively; Table II). A normal proportion 
Table IV. Incorporation of $\left[{ }^{3} \mathrm{H}\right]$-Thymidine into Blood Lymphocytes in Response to Mitogens or IL-2

\begin{tabular}{|c|c|c|c|c|c|c|}
\hline \multirow[b]{2}{*}{ Conditions } & \multicolumn{5}{|c|}{ Subjects } & \multirow[b]{2}{*}{ Normals } \\
\hline & V-E & VI-K & VI-P & VII-A & Group data & \\
\hline Unstimulated & 815 & 440 & 277 & 596 & $532 \pm 299$ & $221 \pm 56$ \\
\hline PHA, $16 \mu \mathrm{g} / \mathrm{ml}$ & 2357 & 338 & 7752 & 4889 & $4596 \pm 2347$ & $49912 \pm 16839$ \\
\hline Con A, $2.5 \mu \mathrm{g} / \mathrm{ml}$ & 2153 & 4864 & 5561 & 2446 & $3756 \pm 1709$ & $33490 \pm 14028$ \\
\hline PWM, 1:100 & 3052 & 6687 & 8727 & 4520 & $5747 \pm 2485$ & $30340 \pm 13092$ \\
\hline IL-2, $10 \mathrm{U}$ & 3183 & 1679 & 4198 & 2345 & $2851 \pm 1088$ & $16181 \pm 12880$ \\
\hline
\end{tabular}

Data are presented in cpm. Group data are presented as the mean $\pm \mathrm{SD}$. Low levels of $\left[{ }^{3} \mathrm{H}\right]$-thymidine incorporation were also found in the lymphocytes from the patients that were exposed to other concentrations of mitogens or IL-2 (data not shown). The results of studies on VI-K conducted at Baylor were similar to those shown below.
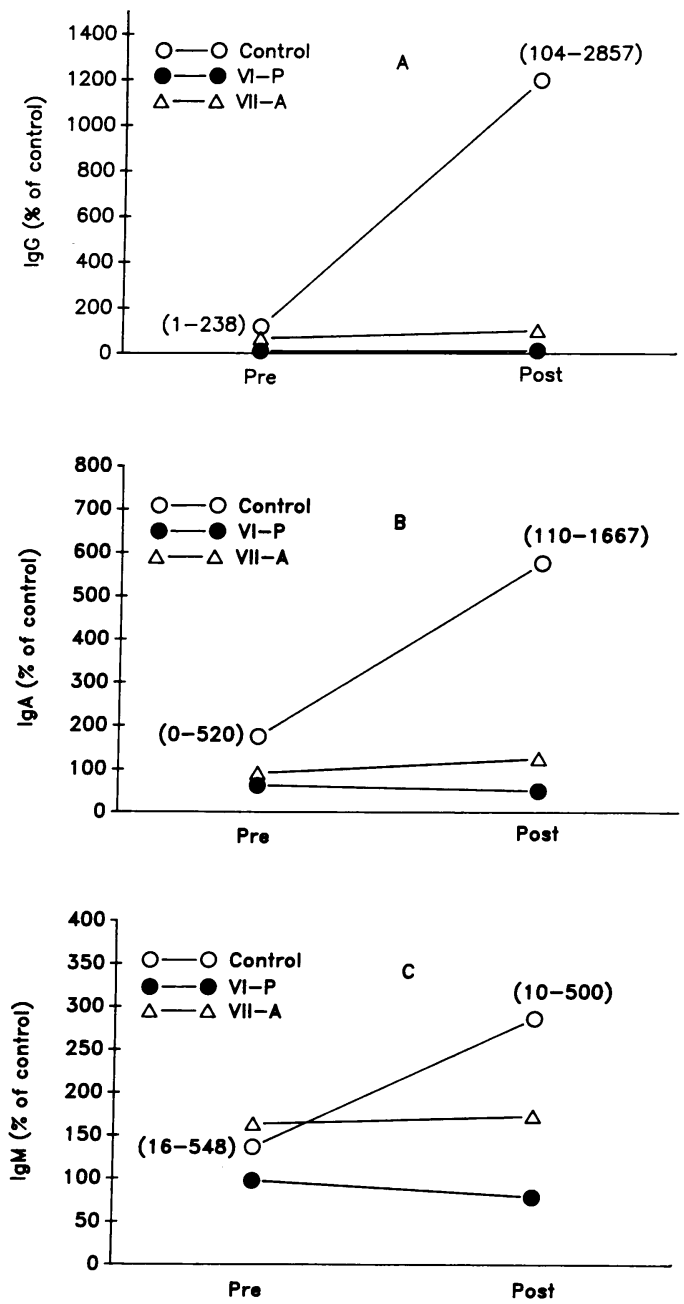

Figure 2. The ability of subjects VI-P and VII-A and eight normal children to form serum $\operatorname{IgG}(A)$, IgA $(B), \operatorname{IgM}(C)$ antibodies to diphtheria toxoid before and after immunization. Antibody titers are expressed as the percent activity of a pool of normal adult sera. Data are presented as the mean of antibody titers from five immunization trials with subject VI-P and four immunization trials with subject VII-A and the mean and range (in parentheses) of titers found in the normal children from a single immunization. The patients' serum IgG antibody titers were greatly decreased. of $\mathrm{T}$ cells from the affected males were found to have IL-2 receptors (Table II). Furthermore, virtually all $\mathrm{CD}^{+}$cells from these patients expressed TCR with $\alpha / \beta$ chains, whereas few were $\gamma / \delta$ positive. Studies on subject VI-K performed at Baylor were similar to the results found in Table II.

Additional investigations were undertaken to determine whether the reductions in $\mathrm{CD}^{+}$or $\mathrm{CD}^{+} \mathrm{T}$ cells could be further pinpointed. Striking deficiencies in $\mathrm{CD}^{+}$cells that

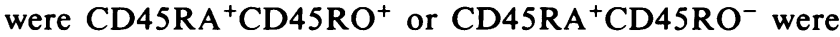
found $(P<0.001)$, whereas $\mathrm{CD}^{2} 4 \mathrm{RA}^{-} \mathrm{CD} 45 \mathrm{RO}^{+}$cells were less affected $(P<0.01$; Table III, Fig. 3$)$.

In the present study a large proportion of CD45RA ${ }^{+}$ $\mathrm{CD}_{45 \mathrm{RO}^{+}}$cells was found in control adults. No double-negative cells were detected. It has previously been reported that $\mathrm{CD} 4 \mathrm{RA}^{+} \mathrm{CD} 45 \mathrm{RO}^{+}$cells comprise $\sim 1 \%$ of the $\mathrm{T}$ cell population in the blood of normal individuals $(41,42)$. Further studies on normal individuals comparing single-, two-, and three-color analyses of the CD45RA and CD45RO subpopulations demonstrated, however, concordance between the three techniques (data not shown). It therefore appears that the results of the three-color estimates of $\mathrm{CD} 45 \mathrm{RA}^{+} \mathrm{CD} 45 \mathrm{RO}^{+}$ cells were reasonable.

Because a low density of CD8 molecules are expressed on the surface of a significant proportion of NK cells (43), twocolor flow cytometry was used to more precisely define the deficiencies in $\mathrm{CD}^{+}$cells. $\sim 86-88 \%$ of $\mathrm{CD}^{+}$positive cells were $\mathrm{CD}^{+}$, except in subject VI-A where $62 \%$ of the $\mathrm{CD}^{+}$ cells were $\mathrm{CD}_{16}{ }^{+} \mathrm{CD}^{-}$.

Lymphocyte proliferation. The responses of blood lymphocytes to allogeneic cells (data not shown), phytomitogens, or $C$. albicans were investigated in subjects VI-K, VI-P, and VII-A. Although some stimulation was evident, the responses were significantly reduced as compared to normal controls ( $P$ $\leq 0.01$; Table IV, Fig. 4).

Cytotoxic activity. Blood mononuclear leukocytes from subjects VI-P and VII-A exhibited slightly elevated or normal lytic (NK) activity, respectively, as compared to normal controls (data not shown).

Interleukin-lymphokine production. The production of IL-2 by PHA-P stimulated blood lymphocytes in the subjects VI-P and VI-K was $\sim 20-25 \%$ of normal. The generation of interferon activity by their blood lymphocytes stimulated with Con A or PHA-P was $94 \%$ and $86 \%$ of normal control values, 


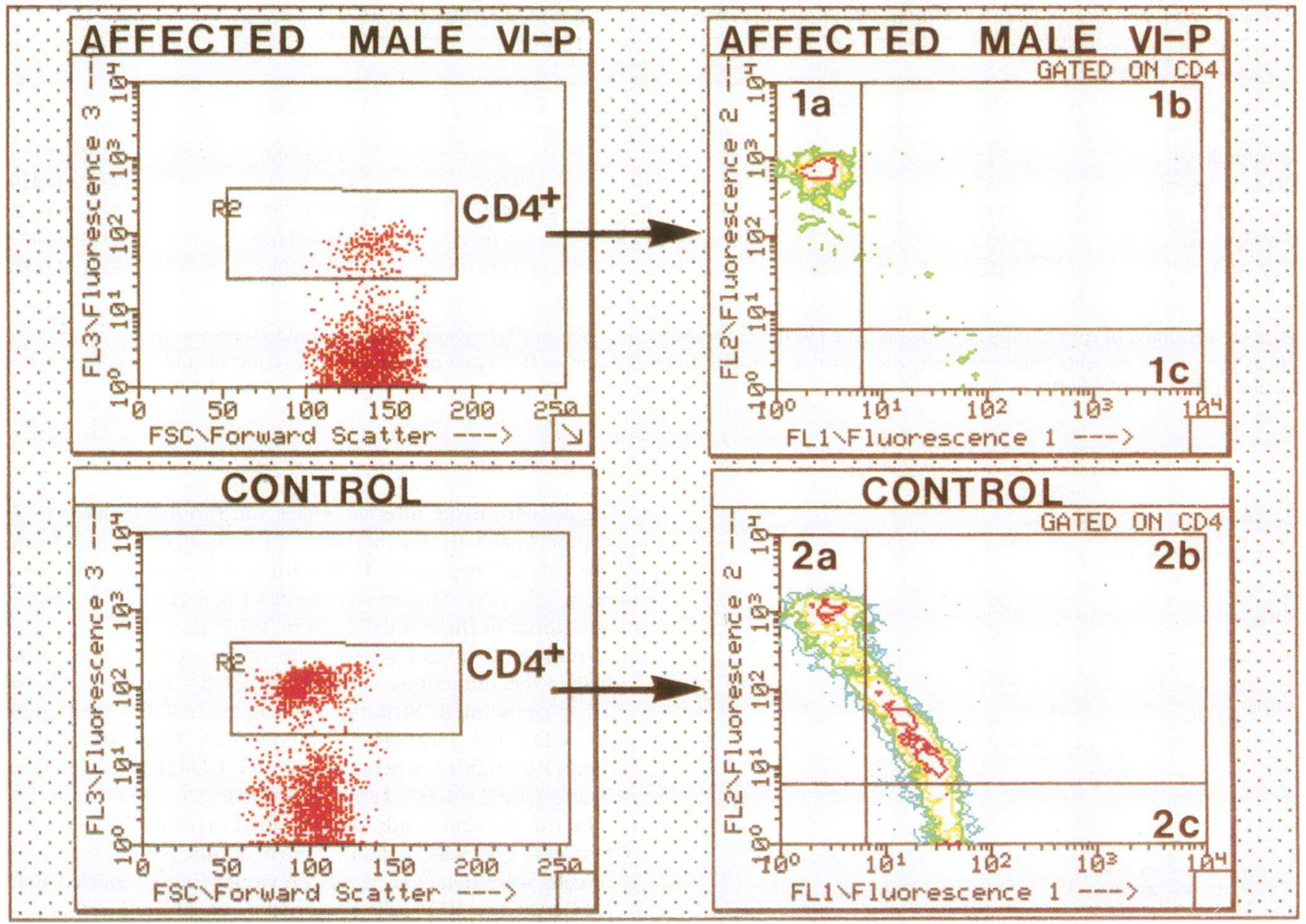

Figure 3. Three-color immunofluorescence flow cytometry of $\mathrm{CD} 4^{+}$blood lymphocytes from subject VI-P (I) and a normal adult (2) stained for CD45RA and CD45RO. Fluorescence 1 was for CD45RA, fluorescence 2 for CD45RO, and fluorescence 3 for CD4. The following designa-

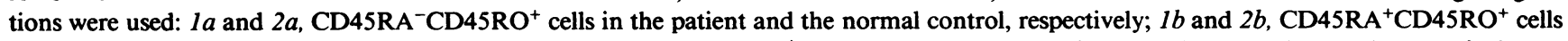

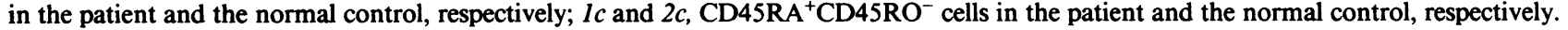

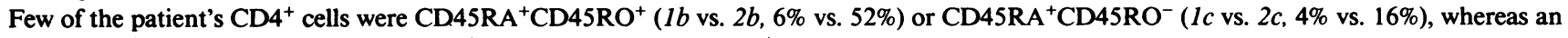
increased proportion of the patient's $\mathrm{CD}^{+}$were $\mathrm{CD}^{+} 5 \mathrm{RA}^{-} \mathrm{CD}^{-} 5 \mathrm{RO}^{+}$( $1 a$ vs. $2 a, 90 \%$ vs. $32 \%$ ).

respectively. Finally, TNF cytotoxic activities in blood lymphocytes stimulated with PHA-P or Con A from subject VI-P were similar to those from normal controls (data not shown).

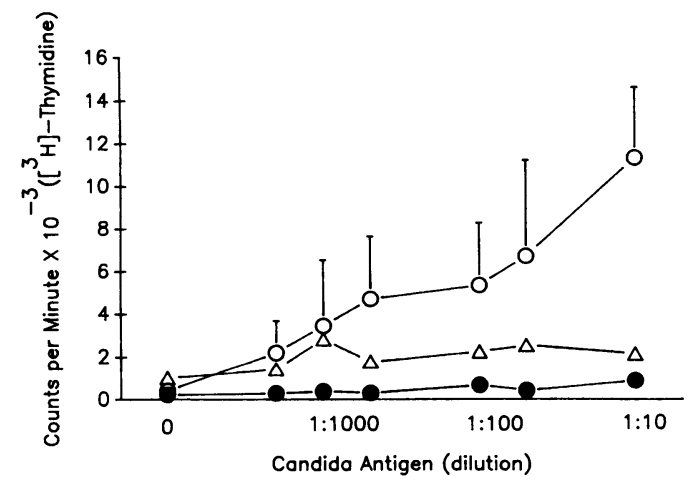

Figure 4. $\left[{ }^{3} \mathrm{H}\right]$-Thymidine uptake of blood lymphocytes in response to $C$. albicans in subjects VI-P $(\bullet)$ and VII-A $(\Delta)$ and normal controls (O) (control data are depicted as the mean $\pm \mathrm{SD}$ ).

\section{Discussion}

Certain clinical and immunologic features of this novel $\mathrm{X}$ linked combined immunodeficiency (CID) were different from the classical types of SCID. (a) The increased susceptibility to infections was often not manifest until the second year of life. (b) Although these patients displayed some of the same kinds of infections that commonly occur in $\operatorname{SCID}(2,3,6)$, the types of opportunistic infections were more restricted in this new disease. In particular, there was no history of infections with $C$. albicans or Pneumocystis carinii. (c) Many of these patients survived past infancy, or even into adulthood. In that regard, the longest-lived individual suspected of having this disease (IV-D) died at age 38 yr. Possibly because of their prolonged survivals, they developed infections with agents such as papillomavirus that are rarely seen in SCID. In that respect, extensive mucosal papillomavirus infections were previously reported in one of the affected males (Fig. 1, subject V-E) (44). (d) In contrast to most cases of SCID, the serum concentrations of the major immunoglobulin isotypes were 
normal, and the deficiencies in specific serum antibody responses were most pronounced for IgG. $(e)$ The deficiencies in the numbers of $\mathrm{CD}^{+} \mathrm{CD}^{+}$and $\mathrm{CD}^{+} \mathrm{CD}^{+}$blood $\mathrm{T}$ cells and their proliferative responses were less marked in this disease than in $\operatorname{SCID}(2,3,6)$. Although these subjects resemble patients with SCID with immunoglobulin production (45), an $X$-linked pattern was never found in previously reported families where all affected males with SCID displayed normal serum concentrations of each immunoglobulin isotype.

A number of observations support the hypothesis that the defect in this new disease is limited to T lymphocytes. (a) The increased susceptibility to the infections with DNA-type viruses is in keeping with a paucity of $\mathrm{T}$ cells in these patients. $(b)$ The findings of normal serum IgM antibody titers and impaired IgG antibody responses to specific immunogens are consistent with a failure of $\mathrm{T}$ cells to regulate the switching of the immunoglobulin class of specific antibodies by B cells. (c) In addition, neither the numbers of $B$ cells nor the concentrations of serum immunoglobulins were low.

We considered whether some of the immunologic dysfunctions in these patients were due to deficiencies in certain $T$ cell subpopulations defined by the T200 isoforms, CD45RA and $C D 45 R O(41,42,46-48)$. Recent reports indicate that the differential expression of CD45RA and CD45RO reflects the degree of differentiation of $T$ cells along a unidirectional pathway $(41,42,46-48)$. In that regard, there is a reciprocal relationship between these isoforms in that immunologically virgin $\mathrm{T}$ cells are $\mathrm{CD} 45 \mathrm{RA}^{+}$and $\mathrm{CD}^{4} 5 \mathrm{RO}^{-}$, whereas antigenprimed or memory $\mathrm{T}$ cells are $\mathrm{CD}_{45 \mathrm{RA}^{-}}$and $\mathrm{CD}^{4} 5 \mathrm{RO}^{+}(41$, 42, 46-48). Cells positive for both CD45RA and CD45RO may be transitional forms that occur due to alternative RNA splicing and a slow turnover of CD45RA (42). There is evidence that $\mathrm{CD}^{+}{ }^{+} \mathrm{CD} 45 \mathrm{RA}^{+}$lymphocytes produce IL-2, respond well to mitogens or self-Ia antigens but not to soluble antigens, and develop into $\mathrm{T}$-memory cells that are $\mathrm{CD}^{2} 5 \mathrm{RA}^{-} \mathrm{CD}^{-} 5 \mathrm{RO}^{+}(41,46-53)$. In addition, they may regulate $\mathrm{B}$ cells by inducing the suppressive activities of $\mathrm{CD} 8^{+} \mathrm{T}$ cells $(47,53)$. In contrast, $\mathrm{CD}^{+} \mathrm{CD}^{+} 5 \mathrm{RA}^{-} \mathrm{CD}^{-} 5 \mathrm{RO}^{+}$cells respond briskly to antigens and produce interferon- $\gamma$, but those isolated cells do not proliferate or produce IL-2 well after exposure to mitogens. In our patients, $\mathrm{CD}^{+}$and $\mathrm{CD}^{+} \mathrm{T}$ lymphocytes were most deficient in subsets expressing CD45RA (CD45RA ${ }^{+}$CD45RO ${ }^{+}$and $\mathrm{CD}^{2} 5 \mathrm{RA}^{+} \mathrm{CD} 45 \mathrm{RO}^{-}$). We feel that the findings are consistent with the notion that the virgin $T$ cells produced in the patients differentiated into primed $\mathrm{T}$ cells. Thus, the defects in IL-2 production and proliferation of mitogen-stimulated blood lymphocytes may be due to deficiencies in $\mathrm{CD}^{+}{ }^{+} \mathrm{CD} 45 \mathrm{RA}^{+}$cells. It might be expected that the patients' $T$ cells would respond to specific antigens,

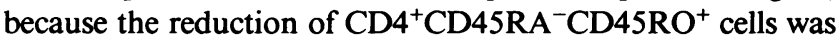
not as pronounced. The responses to Candida by blood lymphocytes from the patients were, however, quite depressed, perhaps because $\mathrm{CD}^{2} 5 \mathrm{RA}^{-} \mathrm{CD} 45 \mathrm{RO}^{+}$cells were too limited in number or in their immunologic repertoire. Further studies of the patients with a number of different antigens may aid to clarify this point. Because of different cytotoxic responses by $\mathrm{CD} 4 \mathrm{RA}^{+}$and $\mathrm{CD} 45 \mathrm{RO}^{-} \mathrm{CD}^{+}{ }^{+} \mathrm{T}$ cells $(54)$, the lytic activity of $\mathrm{T}$ cells in the patients should also be investigated.

Recently, a male born into this family (Fig. 1; subject VII-B) was found to have a $\mathrm{T}$ cell defect during the immediate newborn period. If he has the same genetic defect as the other affected members of the family, the developmental pattern of his thymus and $\mathrm{T}$ and $\mathrm{B}$ cells may provide additional clues to the nature of this disease.

Indeed, an understanding of the basis of this disease will ultimately depend upon a definition of the types of cells that are affected and the molecular abnormalities in those cells. The large size of the family and the prolonged survival of some affected males may provide opportunities to investigate those questions and to map the abnormal gene on the $\mathrm{X}$ chromosome.

\section{Acknowledgments}

The authors thank Dr. Gary R. Klimpel for his help in performing the cytotoxicity, tumor necrosis factor, and interferon assays; Kimberly $\mathrm{H}$. Palkowetz and Mary Douglas for their technical assistance; and Susan C. Kovacevich for her secretarial help.

E. G. Brooks was supported by a grant from the James W. McLaughlin Fellowship Fund of the University of Texas Medical Branch, Galveston, TX.

\section{References}

1. Bruton, O. C. 1952. Agammaglobulinemia. Pediatrics. 9:722727.

2. Rosen, F. S., R. J. Wedgwood, M. Eibl, F. Aiuti, M. D. Cooper, R. A. Good, C. Griscelli, L. A. Hanson, W. H. Hitzig, S. Matsumoto, M. Seligmann, J. F. Soothill, and T. A. Waldmann. 1986. Primary immunodeficiency diseases. Report of a World Health Organization. Clin. Immunol. Immunopathol. 40:166-196.

3. Rosen, F. S., M. D. Cooper, and R. J. P. Wedgwood. 1984. The primary immunodeficiencies. 2. N. Engl. J. Med. 311:300-310.

4. Lederman, H. M., and J. A. Winkelstein. 1985. X-linked agammaglobulinemia: an analysis of 96 patients. Medicine (Baltimore). 64:145-156.

5. Ochs, H. D., and R. J. Wedgwood. 1989. Disorders of the B-cell system in immunologic disorders. In Immunologic Disorders in Infants and Children. E. R. Stiehm, editor. W. B. Saunders Co., Philadelphia. 226-256.

6. Cooper, M. D., H. P. Chase, J. T. Lowman, W. Krivit, and R. A. Good. 1968. Wiskott-Aldrich syndrome: an immunologic deficiency disease involving the afferent limb of immunity. Am. J. Med. 44:499513.

7. Zabay, J. M., G. Fontan, A. Campos, M. C. Garcia-Rodriquez, D. Pascual-Salcedo, A. Bootello, and E. G. de la Concha. 1984. Disorders of regulatory $\mathrm{T}$ cell function in patients with the Wiskott-Aldrich syndrome. Clin. Exp. Immunol. 56:23-28.

8. Ilowite, N. T., C. L. Fligner, H. D. Ochs, B. Brichacek, S. Harada, J. E. Haas, D. T. Purtilo, and R. J. Wedgwood. 1986. Pulmonary angiitis with atypical lymphoreticular infiltrates in Wiskott-Aldrich syndrome: possible relationship of lymphomatoid granulomatosis and EBV infection. Clin. Immunol. Immunopathol. 41:479-484.

9. Kenney, D., L. Cairns, E. Remold-O’Donnell, J. Peterson, F. S. Rosen, and R. Parkman. 1986. Morphological abnormalities in the lymphocytes of patients with the Wiskott-Aldrich syndrome. Blood. 68:1329-1332.

10. Purtilo, D. T., E. Tatsumi, G. Manolov, Y. Manolova, S. Harada, H. Lipscomb, and G. Krueger. 1985. Epstein-Barr virus as an etiological agent in the pathogenesis of lymphoproliferative and aproliferative diseases in immune deficient patients. Intl. Rev. Exp. Pathol. 27:113-183.

11. Grierson, H., and D. T. Purtilo. 1987. Epstein-Barr virus infections in males with the X-linked lymphoproliferative syndrome. Ann. Intern. Med. 106:538-545. 
12. Mathe, G. 1983. Virus EBV, immunodeficience, aplasie medullaire, mononucleose maligne et syndrome lymphoproliferatif $B$ lie au sexe (XLP). Biomed. \& Pharmacother. 37:249-250.

13. Gallin, J. I., E. S. Buescher, B. E. Seligmann, J. Nath, T. Gaither, and P. Katz. 1983. Recent advances in chronic granulomatous disease. Ann. Intern. Med. 99:657-674.

14. Ezekowitz, R. A., S. H. Orkin, and P. E. Newburger. 1987. Recombinant interferon gamma augments phagocyte superoxide production and $\mathrm{X}$-chronic granulomatous disease gene expression in $\mathrm{X}$ linked variant chronic granulomatous disease. J. Clin. Invest. 80:1009-1016.

15. Gelfand, E. W., and H.-M. Dosch. 1983. Diagnosis and classification of severe combined immunodeficiency disease. In Primary Immunodeficiency Diseases. Birth Defects Original Article Series. Vol. 19. R. J. Wedgwood, F. S. Rosen, and N. W. Paul, editors. Alan R. Liss, Inc., New York. 65-72.

16. Hirschhorn, R. 1983. Genetic deficiencies of adenosine deaminase and purine nucleoside phosphorylase: overview, genetic heterogeneity and therapy. In Primary Immunodeficiency Diseases. Birth Defects Original Article Series. Vol. 19. R. J. Wedgwood, F. S. Rosen, and N. W. Paul, editors. Alan R. Liss, Inc., New York. 73-81.

17. Schmalstieg, F. C., J. A. Nelson, G. C. Mills, T. M. Monahan, A. S. Goldman, and R. M. Goldblum. 1977. Increased purine nucleotides in adenosine deaminase-deficient lymphocytes. J. Pediatr. 91:48-51.

18. Buckley, R. H., S. E. Schiff, H. A. Sampson, R. I. Schiff, M. L. Markert, A. P. Knutsen, M. S. Hershfield, A. T. Huang, G. H. Mickey, and F. E. Ward. 1986. Development of immunity in human severe primary $\mathrm{T}$ cell deficiency following haploidentical bone marrow stem cell transplantation. J. Immunol. 136:2398-2407.

19. Conley, M. E., P. Brown, A. R. Pickard, R. H. Buckley, D. S. Miller, W. H. Raskind, J. W. Singer, and P. J. Fialkow. 1986. Expression of the gene defect in X-linked agammaglobulinemia. $N$. Engl. J. Med. 315:564-567.

20. Mensink, E. J., A. Thompson, J. D. Schot, W. M. van-de-Greef, L. A. Sandkuyl, and R. K. Schuurman. 1986. Mapping of a gene for $\mathrm{X}$-linked agammaglobulinemia and evidence for genetic heterogeneity. Hum. Genet. 73:327-332.

21. Kwan, S.-P., L. Kunkel, G. Bruns, R. J. Wedgwood, S. Latt, and F. S. Rosen. 1986. Mapping of the X-linked agammaglobulinemia locus by use of restriction fragment-length polymorphism. J. Clin. Invest. 77:649-652.

22. Mensink, E. J., A. Thompson, L. A. Sandkuyl, M. E. Kraakman, J. D. Schot, T. Espanol, and R. K. Schuurman. 1987. X-linked immunodeficiency with hyperimmunoglobulinemia $M$ appears to be linked to the DXS42 restriction fragment length polymorphism locus. Hum. Genet. 76:96-99.

23. Peacocke, M., and K. A. Siminovitch. 1987. Linkage of the Wiskott-Aldrich syndrome with polymorphic DNA sequences from the human X chromosome. Proc. Natl. Acad. Sci. USA. 84:34303433

24. Skare, J. C., H. L. Grierson, J. L. Sullivan, R. L. Nussbaum, D. T. Purtilo, B. S. Sylla, G. M. Lenoir, D. S. Reilly, B. N. White, and A. Milunsky. 1989. Linkage analysis of seven kindreds with the Xlinked lymphoproliferative syndrome (XLP) confirms that the XLP locus is near DXS42 and DXS37. Hum. Genet. 82:354-358.

25. Baehner, R. L., L. M. Kunkel, A. P. Monaco, J. L. Haines, P. M. Conneally, C. Palmer, N. Heerema, and S. H. Orkin. 1986. DNA linkage analysis of $\mathrm{X}$ chromosome-linked chronic granulomatous disease. Proc. Natl. Acad. Sci. USA. 83:3398-3401.

26. de-Saint-Basile, G., B. Arveiler, I. Oberle, S. Malcolm, R. J. Levinsky, Y. L. Lau, M. Hofker, M. Debre, A. Fischer, C. Griscelli, and J. L. Mandel. 1987. Close linkage of the locus for X chromosomelinked severe combined immunodeficiency to polymorphic DNA markers in Xq11-q13. Proc. Natl. Acad. Sci. USA. 84:7576-7579.

27. Puck, J. M., R. L. Nussbaum, D. L. Smead, and M. E. Conley 1989. X-linked severe combined immunodeficiency: localization within the region Xq13.1-q21.1 by linkage and deletion analysis. $\mathrm{Am}$. J. Hum. Genet. 44:724-730.

28. Mensink, E. J., and R. K. Schuurman. 1987. Immunodeficiency disease genes on the X chromosome. Dis. Markers. 5:129-140.

29. Dinauer, M. C., and S. H. Orkin. 1988. Chronic granulomatous disease. Molecular genetics. Hematol. Oncol. Clin. North Am. 2:225240.

30. Dinauer, M. C., S. H. Orkin, R. Brown, A. J. Jesaitis, and C. A. Parkos. 1987. The glycoprotein encoded by the X-linked chronic granulomatous disease locus is a component of the neutrophil cytochrome b complex. Nature (Lond.). 327:717-720.

31. Mentzer, S. J., E. Remold-O’Donnell, M. A. Crimmins, B. E. Bierer, F. S. Rosen, and S. J. Burakoff. 1987. Sialophorin, a surface sialoglycoprotein defective in the Wiskott-Aldrich syndrome, is involved in human T lymphocyte proliferation. J. Exp. Med. 165:13831392.

32. Killingsworth, L. M., and J. Savory. 1971. Automated immunochemical procedures for measurement of immunoglobulins IgG, IgA, and IgM in human serum. Clin. Chem. 17:936-940.

33. Hamilton, R. G., R. W. Wilson, T. Spillman, and M. Roebber. 1988. Monoclonal antibody-based immunoenzymetric assays for quantification of human IgG and its four subclasses. J. Immunoassay. 9:275-296.

34. Goldman, A. S., C. Garza, B. L. Nichols, and R. M. Goldblum. 1982. Immunologic factors in human milk during the first year of lactation. J. Pediatr. 100:563-567.

35. Jackson, A. L., and N. L. Warner. 1986. Preparation, staining, and analysis by flow cytometry of peripheral blood leukocytes. In Manual of Clinical Laboratory Immunology. 3rd ed. N. R. Rose, H. Friedman, and J. L. Fahey, editors. American Society for Microbiology, Washington, DC. 226-235.

36. Lu, L. I., E. F. Srour, D. J. Warren, D. Walker, C. D. Graham, E. B. Walker, J. Jansen, and H. E. Broxmeyer. 1988. Enhancement of release of granulocyte- and granulocyte-macrophage colony-stimulating factors from phytohemagglutinin-stimulated sorted subsets of human $\mathrm{T}$ lymphocytes by recombinant human tumor necrosis factor$\alpha$. Synergism with recombinant human IFN- $\gamma$. J. Immunol. 141:201207.

37. Pross, H. F., M. G. Baines, P. Rubin, P. Shragge, and M. S. Patterson. 1981. Spontaneous human lymphocyte-mediated cytotoxicity against tumor target cells. IX. The quantitation of natural killer cell activity. J. Clin. Immunol. 1:51-63.

38. Gillis, S., M. M. Ferm, W. Ou, and K. A. Smith. 1978. T cell growth factor: parameters of production and a quantitative microassay for activity. J. Immunol. 120:2027-2032.

39. Campbell, J. B., T. Grunberger, M. A. Kochman, and S. L. White. 1975. A microplaque reduction assay for human and mouse interferon. Can. J. Microbiol. 21:1247-1253.

40. Flick, D. A., and G. E. Gifford. 1984. Comparison of in vitro cell cytotoxic assays for tumor necrosis factor. J. Immunol. Methods. 68:167-175.

41. Akbar, A. N., L. Terry, A. Timms, P. C. L. Beverley, and G. Janossy. 1984. Loss of CD45R and gain of UCHL1 reactivity is a feature of primed T cells. J. Immunol. 140:2171-2178.

42. Deans, J. P., A. W. Boyd, and L. M. Pilarski. 1989. Transition from high to low molecular weight isoforms of CD45 (T200) involve a rapid activation of alternate mRNA splicing and slow turnover of surface CD45R. J. Immunol. 143:1233-1238.

43. Lanier, L. L., A. M. Le, J. H. Phillips, N. L. Warner, and G. F. Babcock. 1983. Subpopulations of human natural killer cells defined by expression of the Leu-7 (HNK-1) and Leu-11 (NK-15) antigens. $J$. Immunol. 131:1789-1796.

44. Feldman, S. B., F. M. Sexton, J. D. Glenn, and D. P. Lookingbill. 1989. Immunosuppression in men with bowenoid papulosis. Arch. Dermatol. 125:651-654.

45. Ammann, A. J., and R. Hong. 1989. Disorders of the T-cell 
system. In Immunologic Disorders In Infants and Children. E. R. Stiehm, editor. W. B. Saunders Co., Philadelphia. 257-315.

46. Merkenschlager, M., L. Terry, R. Edwards, and P. C. Beverley. 1988. Limiting dilution analysis of proliferative responses in human lymphocyte populations defined by the monoclonal antibody UCHL1: implications for differential CD45 expression in T cell memory formation. Eur. J. Immunol. 18:1653-1661.

47. Clement, L. T., N. Yamashita, and A. M. Martin. 1988. The functionally distinct subpopulations of human $\mathrm{CD}^{+}$helper/inducer $\mathrm{T}$ lymphocytes defined by anti-CD45R antibodies derive sequentially from a differentiation pathway that is regulated by activation-dependent post-thymic differentiation. J. Immunol. 141:1464-1470.

48. Byrne, J. A., J. L. Butler, and M. D. Cooper. 1988. Differential activation requirements for virgin and memory $\mathrm{T}$ cells. J. Immunol. 141:3249-3257.

49. Dohlsten, M., G. Hedlund, H. O. Sjogren, and R. Carlsson. 1988. Two subsets of human $\mathrm{CD}^{+} \mathrm{T}$ helper cells differing in kinetics and capacities to produce interleukin 2 and interferon-gamma can be defined by the Leu-18 and UCHL1 monoclonal antibodies. Eur. J. Immunol. 18:1173-1178.
50. Salmon, M., G. D. Kitas, J. S. Hill Gaston, and P. A. Bacon. 1988. Interleukin-2 production and response by helper $T$ cell subsets in man. Immunology. 65:81-85.

51. Salmon, M., G. D. Kitas, and P. A. Bacon. 1989. Production of lymphokine mRNA by $\mathrm{CD}^{2} 5 \mathrm{R}^{+}$and $\mathrm{CD} 45 \mathrm{R}^{-}$helper $\mathrm{T}$ cells from human peripheral blood and by human $\mathrm{CD}^{+} \mathrm{T}$ cell clones. $\mathrm{J}$. Immunol. 143:907-912.

52. Sanders, M. E., M. W. Makgoba, S. O. Sharrow, D. Stephany, T. A. Springer, H. A. Young, and S. Shaw. 1988. Human memory T lymphocytes express increased levels of three cell adhesion molecules (LFA-3, CD2, and LFA-1) and three other molecules (UCHL1, CDw29, and pgp-1) and have enhanced IFN-gamma production. $J$. Immunol. 140:1401-1407.

53. Rudd, C. E., P. Anderson, C. Morimoto, M. Streuli, and S. F. Schlossman. 1989. Molecular interactions, T-cell subsets and a role of the CD4/CD8:p56 $6^{\text {lck }}$ complex in human T-cell activation. Immunol. Rev. 111:225-266.

54. Yamashita, N., and L. T. Clement. 1989. Phenotypic characterization of the post-thymic differentiation of human alloantigen-specific $\mathrm{CD}^{+}$cytotoxic T lymphocytes. J. Immunol. 143:1518-1523. 